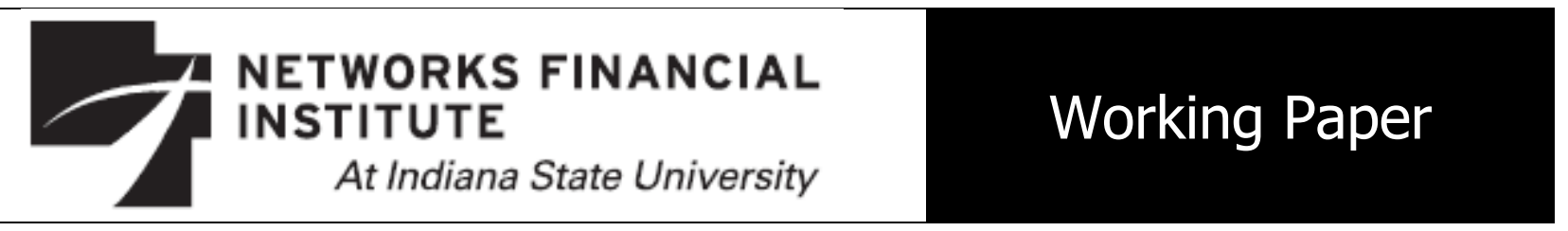

2011-WP-22

September 2011

\title{
Does It Pay to Invest in Debt Free Firms During Recessions? Tarek Zaher
}

Abstract: This study attempts to find out whether investors reward firms that carry no debt and penalize firms that carry large amount of debt during recessions. I compare the performance of portfolios of large cap debt free firms to comparable portfolios of leveraged firms during the last recession. The results of the study suggest that investments in portfolios of debt free firms tend to generate higher returns than investments in portfolios of leveraged firms during recessions. The evidence presented here has clear implications for investors and portfolio managers. During market downturns, debt free firms will not have the additional burden of debt and may be able to recover much quicker than leveraged firms, and therefore they would outperform their peers of leveraged firms. Investors would therefore be better off if a larger portion of their equity investment is allocated to debt free firms rather than leveraged firms.

About the Author: Tarek Zaher is a Professor of Finance, Indiana State University College of Business. Dr. Zaher completed his Ph.D. at the University of Texas at Dallas. He has taught at Indiana State University since 1990 and previously taught at the University of Texas at Arlington. Dr. Zaher has held professional jobs with and provided consulting services to a number of companies in the United States and abroad. Dr. Zaher also has offered seminars in investment and international finance at institutions around the world and has published in numerous scholarly journals. Dr. Zaher's primary research is in financial markets and institutions and investment, with a special interest in emerging markets including the Middle Eastern and North African (MENA) markets.

Keywords: Performance of Debt Free Firms, Good Balance Sheet Firms, Recessions, Financial Leverage, Expected Stock Returns, Zero Debt Firms.

The views expressed are those of the individual author and do not necessarily reflect official positions of Networks Financial Institute. Please address questions regarding content to Tarek Zaher at Tarek.Zaher@indstate.edu. Any errors or omissions are the responsibility of the author.

NFI working papers and other publications are available on NFI's website (www.networksfinancialinstitute.org). Click "Thought Leadership" and then "Publications/Papers." 


\section{Does It Pay to Invest in Debt Free Firms During Recessions?}

\section{Introduction}

The National Bureau of Economic Research (NBER), which determines when recessions in the United States officially begin and end, has recognized 32 recessionary periods since 1857. On average, these recessions last 17 months. NBER declared December 2007-June 2009 as the dates for the latest recession. The trend has been toward fewer and shorter recessions since the end of World War II. However, this does not hold true for the latest great recession; instead it was about average from a longer term perspective. Moreover, some economists, money managers, market observers, and investors are concerned about a second dip of recession in the near future. Previous evidence suggests that each recession is different, and the current one has introduced extreme levels of volatility in equity markets overall. It also has had a major impact on businesses around the world. Some large multinational firms had to shut down brands, businesses and branches, and many small firms had to close altogether. As the world is emerging from the current recession, many firms have had to raise large amounts of debt to stay alive. Companies with plenty of liquid assets, on the other hand, have kept away from the temptation of borrowing and were able to keep their heads above water through the crisis.

Institutional investors and portfolio managers usually maintain a strategic asset allocation based on long term performance expectations. However they sometimes try to capitalize on shorter term anomalies through tactical shifts in asset mixes. Timing these shifts is difficult, so investors are keenly interested to understand any patterns in performance that appear to persist over time and can be exploited for tactical purposes. A number of studies have examined the performance patterns of stocks of different capitalization ranges as the U.S. economy enters and passes through recessionary periods. Some of these studies have noted small cap stocks historically have tended to outperform larger stocks in the later stages of the recession and well into the recovery period. Typically, small cap stocks are highly leveraged (more debt) and tend to have more volatile performance histories. Higher leverage becomes a drag as interest rates increase and provides a lift as rates dropped. Companies with greater dependence on debt tend to suffer as credit tightens during recessionary periods, but benefit as credit loosens during expansion.

As in any investment decision, careful attention to market conditions and risk are critical to the investor's overall success, especially during volatile times when share prices are likely to 
remain erratic. Many investors try to play it safe and invest in large capitalization stocks that tend to be less volatile during recessions and some investors concentrate on firms with strong balance sheet, few debts and a healthy cash flow. It is these companies that are better placed to survive a recession and prosper when the recovery finally arrives. Given the scale of the credit crunch in the last great recession, it is obvious that any company that has significant debts on its books is at a disadvantage to one that has no debt. In the aftermath of the global financial crisis, debt remains a problem for highly leveraged firms. Typically, indebted companies may no longer be able to refinance their debts at such favorable terms, which will push up their costs. And there is also the fear that credit lines could be cancelled altogether. Companies that have no debt on their books, on the other hand, are in a more defensive position and they may also be better placed to profit from any future recovery. Hence investments in debt free companies during recessions are expected to reward investors.

The capital structure literature indicates that limited work has been undertaken in examining the impact of leverage on stock returns, largely due to the overwhelming influence of the work of Miller and Modigliani (MM, 1958). MM argue that equity returns should not increase with leverage. However, the empirical evidence on the relationship between financial leverage and stock returns is contradictory and mixed. Some studies suggest that there is a positive relationship between leverage and stock returns. Bhandari (1988) provides evidence that common stock returns increase with leverage. Other studies provide evidence that there is a negative relationship between leverage and stock returns. Fama and French (1992) find that leverage based on book values is associated with lower average returns, whereas leverage based on market values is associated with higher returns. Korteweg (2004) also reports a negative relation between stock returns and leverage. Penman et al (2007) find that leverage is negatively related to returns. Zaher (2010) provides evidence that investors tend to reward firms that resist the urge to borrow and operate with debt free balance sheets and penalize firms that have high levels of debt. The results of the study indicate that investments in portfolios of debt free firms tend to generate higher returns than investments in their peers of portfolios of leveraged firms over long and short periods. The results of the study raise again the question about the optimal level of debt a firm should have and whether investors should invest in low debt or high leveraged firms, especially during periods of economic downturns or financial crises. 
In this study, I focus on the impact of leverage on equity returns of large cap firms during recessionary periods. I examine whether large cap firms that carry no debt on their balance sheet are rewarded during recessions. In particular, I compare the performance of portfolios of large cap debt free firms to comparable portfolios of leveraged firms. The results of this study indicate that investments in portfolios of large cap debt free firms tend to generate higher returns than investments in their leveraged peers during recessions. These results imply that investors tend to reward firms that resist the urge to borrow heavily and operate with a debt free balance sheet during recessions and to penalize firms that have high levels of debt.

The remainder of the paper is organized as follows: section 2 describes the data and sample selection. In section 3, the research methodology utilized in the study is explained. The empirical results of the study are presented in section 4 and section 5 presents the summary and conclusions.

\section{Data and Samples Selection}

The initial sample of firms used in this study consists of all large capitalizations firms that are listed on the American exchanges during the period of the last recession, December 2007 through June 2009. Two samples of firms are constructed from the initial sample, a debt free firm sample and a leveraged firm sample. Debt free firms are firms with zero total debt and a zero debt to equity ratio. Leveraged firm are firms with a debt to equity ratio that is equal or greater than 15 percent. The firms in the debt free sample were selected first. The requirement for each firm to enter the sample is to have zero total debt and have stock returns series available for the period of the study. The firms in the debt free sample were sorted by sector and capitalization. The leveraged firm sample was then constructed by matching the debt free firms with leveraged firms from the same sector and with comparable market capitalization. Of the twelve sectors, only six sectors contained large cap firms with no debt on their balance sheet during the period of the study. These are technology, services, industrial goods, healthcare consumer goods and basic materials.

Descriptive statistics (monthly mean return, average standard deviation, and average coefficient of variation) and two performance measures, Jensen's alpha and the annualized information ratio, are then computed for the portfolios of debt free firms and leveraged firms in each of sectors and the combined portfolios of all sectors. The screening of sectors and firms 
within each sector is based on yahoo finance. The monthly return data for individual firms and market indexes are extracted from the Center for Research in Security Prices (CRSP) database. The return on the three month Treasury bill is obtained from online Federal Reserve data.

\section{Research Method}

Two alternative measures of performance are used in this study to compare the performance of debt free firms and leveraged firms, the Jensen's alpha, $\alpha_{p}$; and the Sharp information ratio, $S_{p}$. Jensen's alpha depends on beta as a measure of the risk of the portfolio. I estimate the Jensen's alpha $\alpha_{p}$ from the estimated equation for:

$$
r_{p t}=\alpha_{p}+\beta_{p} r_{m t}+\varepsilon_{p t}
$$

where $r_{p t}$, is the excess return (i.e., the observed return minus the risk free rate) on the portfolio $p$ in month $t ; r_{m t}$ is the excess return on the benchmark or market portfolio in month $t ; \beta_{p}$ is portfolio $p$ 's beta; and $\varepsilon_{p t}$ is the residual term during period $t$. The latter error term is normally distributed $\left(0, \sigma_{e}\right)$.

The second measure of investment performance is the Sharp information ratio. This statistic measures the portfolio's average return in excess of a benchmark portfolio divided by the standard deviation of this excess return. The information ratio is calculated as

$$
I R_{j}=\left(R,-R_{b}\right) / \sigma_{E R}
$$

Where:

$I R_{j}=$ the information ratio for portfolio $\mathrm{j}$;

$R_{j}=$ the average return for portfolio $j$ during the specified time period;

$R_{b}=$ the average return on the benchmark or market portfolio during the period; and

$\sigma_{E R}=$ the standard deviation of the excess return during the period.

Goodwin (1998) shows that if excess portfolio returns are estimated with historical data using the same single factor model used to estimate Jensen's alpha, the IR simplifies to

$$
I R_{j=} \alpha_{j} / \sigma_{e}
$$


where $\sigma_{e}$ is the standard error of the error term in the regression in equation 1.

To convert the information ratio that is based on a periodic returns measured $\mathrm{T}$ times per year to an annualized information ratio, the following formula is used:

$$
\text { Annualized IR }=(T) \alpha_{j} /\left(T^{\wedge} 0.5\right) \sigma_{e}=\left(T^{\wedge} 0.5\right) I R
$$

Grinold and Khan (2000) suggest that a reasonable information ratio should fall between 0.50 and 1.0. An annualized information ratio of 0.5 indicates good performance and an IR of 1.0 indicates exceptional performance.

\section{Results}

Table 1 provides listing of all large cap firms that have zero level of debt during the period of the study and used here. The table reports the names and market capitalization for the firms that passed the screening process within each of the sectors and have a market cap of $\$ 5$ billion or more and have no debt on their balance sheet. The market cap for the 19 firms in the technology sector ranged between $\$ 5.1$ billion and $\$ 317.5$ billion. Seven firms with zero debt were identified in the services sector with a market cap between $\$ 6.5$ billion and $\$ 85.2$ billion. The market caps for the two debt free firms identified in the industrial goods sector are $\$ 5.5$ billion and $\$ 9.3$ billion, while the market cap for the debt free firms that survived the screening process in the healthcare sector are $\$ 10.6$ billion and $\$ 13.5$ billion. Three firms passed the screening process in the consumer goods sector and three firms in the basic materials sector. The range of the market cap for the debt free firms in the consumer goods and basic materials sectors is $\$ 6.1$ billion to 6.4 billion and $\$ 5$ billion to $\$ 7.6$ respectively.

Table 2 contains the leveraged firms that matched the zero debt firms in the first sample and passed the screening process. These are the firms that have a market cap of $\$ 5$ billion or greater and have a debt ratio equal to or greater than 15 percent. The table reports market capitalization, total debt, and debt to equity ratio of these firms. The market cap for the 26 matching leveraged firms in the technology sector ranged between $\$ 5.2$ billion and $\$ 20.3$ billion, and the debt ratio is between 0.151 and 0.975 . The market cap for the 14 leveraged firms in the services sector ranged between $\$ 27.8$ billion and $\$ 83.6$ billion and the debt ratio is between 0.153 and 0.440 . The market cap for the 11 matching leveraged firms in the industrial goods sector is between $\$ 5.6$ 
billion and $\$ 22.2$ billion and the debt ratio is between 0.27 and 0.60 . Three matching firms were identified in the healthcare sector with a market cap between $\$ 10.3$ billion and $\$ 13.1$ billion, and debt ratio between 0.15 and 0.48 , and eight matching leveraged firms were identified in the consumer goods sector with a market cap between $\$ 6.3$ billion and $\$ 6.6$ billion, and a debt ratio between 0.15 and 0.54 . In the basic materials sector, eleven leveraged firms were identified with a market cap between $\$ 5.6$ billion and 22.2 billion, and a debt ratio between 0.186 and 0.606 .

Table 3 provides the descriptive statistics (monthly mean return, average standard deviation and average coefficient of variation) of the portfolios of leveraged firms and debt free firms in each of the sectors and the $\mathrm{Z}$ scores from the Wilcoxon test for the period of the last recession, December 2007-June 2009. The mean monthly return is positive for the zero debt firms and negative for leveraged firms in the technology sector. The average standard deviation and the coefficient of variation are larger for the leveraged firms than the zero debt firms, indicating higher risk associated with the leveraged firms. The descriptive statistics in the services sector are similar to those in the technology sector. The mean monthly return is positive for the zero debt firms and negative for the leveraged firms, and the standard deviation and coefficient of variation are larger for the leveraged firms. The mean monthly returns for the firms in the industrial goods sector are negative for both groups of firms, and the standard deviation and coefficient of variation are approximately equal in both groups. The mean monthly return in the healthcare sector is positive for the zero debt firms, while the standard deviation and coefficient of variation are larger in the zero debt firms' sample. The consumer goods sector shows a negative mean monthly return for both groups of firms, but the standard deviation and coefficient of variation are larger for the zero debt firms. In the basic material sector, the mean monthly returns is positive for the zero debt firms and it is negative for the leveraged firms while the standard deviation and coefficient of variations are comparable.

The overall mean monthly returns are positive is positive for the whole sample of debt firms and negative for the leveraged firms. The $\mathrm{Z}$ scores test for difference in means indicates that the mean monthly return of debt free firms is significantly different from that of the leveraged firms. The $\mathrm{Z}$ score is 2.65 and is significant at the 5 percent level. The $\mathrm{Z}$ score of the average standard deviation of monthly return is 2.13 and is also significant at the 5 percent level. The average coefficient of variation for the two groups is significant at the 10 percent level. The $\mathrm{Z}$ score is 
1.73 , indicating that in terms of total variability of monthly return, rather than market related variability, the leveraged firms have higher volatility.

Table 4 reports the estimated beta from the regressions, the performance measures (Jensen's alpha and Sharp IR) and the Z scores for difference in means over the period of the last recession (December 2007-June 2009). The Jensen alpha was computed from equation (1) using a National Association of Securities Dealers Automated Quotation (NASDAQ) equally weighted index from the CRSP as a benchmark. Sharp IR is calculated by dividing the estimated alpha from the regression in equation (1) by the regression standard error. This statistics is then annualized by multiplying the monthly IR by the square root of 12 .

The alpha estimates in Table 3 are positive and statistically significant for the debt free portfolios of all individual sectors, except the portfolio from the consumer goods sector. The alpha is also positive and significant for the combined all sectors debt free portfolio.

The alpha estimates for the leveraged portfolios are mixed in sign and are statistically significant for any of the sectors and the combined portfolio of all sectors. The size of alpha is larger for the debt free firm portfolios for all sectors and the combined portfolio. These results indicate that portfolios of debt free firms outperform their leveraged peers during the period of the last recession.

The above conclusion is also supported by the results from the estimated annualized sharp information ratio. The annualized IR for the combined debt free portfolio is 1.17 and ranges between 0.321 and 0.99 for all the individual sector portfolios. It is only low for the consumer goods portfolio. These estimated annualized IR suggest very good to exceptional performance for all debt free groups of portfolios. The only exception is the consumer goods portfolio. The estimated annualized IR for the leveraged firms portfolios is below 0.5 for all sectors and for the combined portfolio. These results suggest that the leveraged firm's portfolios underperform the matching debt free portfolios. The results of the Wilcoxon two-sample test also confirm these findings. The Z score for the Jensen's alpha is 2.17 and the $\mathrm{Z}$ score for the annualized Sharp IR is 2.13 Both $\mathrm{Z}$ scores are significant at the 5 percent level. However, the $\mathrm{Z}$ score for the difference in beta means is not statistically significant, indicating that there is no difference in systematic risk between the debt free and leveraged portfolios. The later finding indicate that a portfolio of debt free securities constructed from the six sectors examined in this study will outperform a comparable portfolio of leveraged firms 
The findings in this study support those of Dimitrov and Jain (2006), Korteweg (2004), Penman et al (2007). Zaher (2010), who provided evidence that that there is a negative relationship between leverage and stock returns, contradicts the study by Bhandari (1988), who argues that stock returns increase with leverage.

\section{Conclusion}

This study attempts to find out whether investors reward firms that carry no debt and penalize firms that carry large amount of debt during the recent economic downturn. It compares the performance of portfolios of debt free firms to comparable portfolios of leveraged firms during the period of the last recession, December 2007-June 2009. A portfolio of large capitalization firms who carry no debt on their balance sheet were matched with conventional firms of the same size and from the same sector. Tests of differences in the performance are conducted for each sector and the combined portfolios. The results of the study suggest that investments in portfolios of debt free firms tend to generate higher returns than investments in their peers of portfolios of leveraged firms during recessions. The evidence presented here has clear implications for investment performance. Investors would be better off if they concentrate their portion of equity investments in debt free firms rather than leveraged firms during recessions. During market downturns, debt free firms will not have the additional burden of debt and may be able to recover much quicker than companies with levels of debt and therefore would outperform their peers of leveraged firms. 


\section{References}

Bhandari, L. C. (1988). "Debt/Equity Ratio and Expected Common Stock Returns: Empirical Evidence," Journal of Finance XLIII, 507-528.

Dimitrov, Valentin and Jain, Prem C. (2006). "The Value Relevance of Changes in Financial Leverage" (March 15). Available at SSRN: http://ssrn.com/abstract=708281.

Fama, E. F. and French, K. (1992). “The Cross-Section in Expected Stock Returns,” Journal of Finance 47, 427-466.

Fama, E. F. and MacBeth, J. D. (1981). "Risk, Return and Equilibrium: Empirical Tests," Journal of Political Economy 73, 607-636.

Goodwin, T. H. (1998). “The Information Ratio,” Financial Analysts Journal 54(4), 34-43.

Grinold, R. C. and R. N. Khan. (2000). Active Portfolio Management: A Quantitative Approach for Producing Superior Returns and Controlling Risk, $2^{\text {nd }}$ ed. NY: McGraw Hill.

Korteweg, A. (2004). "Financial Leverage and Expected Stock Returns: Evidence from Pure Exchange Offers," available at: http://ssrn.com/abstract=597922 (accessed 10 February 2009).

Modigliani, F. and Miller M. H. (1958). "The Cost of Capital, Corporation Finance and The Theory of Investment," American Economic Review 48(3), 261- 297.

Myers, Stewart C. and Nicholas S. Majluf. (1984). "Corporate Financing and Investment Decisions When Firms Have Information That Investors Do Not Have," Journal of Financial Economics 13, 187-221.

Penman, S. H., Richardson, S. A. and Tuna, I. (2007). "The Book-to-Price Effect in Stock Returns: Accounting for Leverage," Journal of Accounting Research 45(2), 427-467.

Ross, S. A. (1977). “The Determination of Financial Structure: The Incentive-Signaling Approach,” Bell Journal of Economics 8(1), 23-34.

Stulz, R.M. (1990). "Managerial Discretion and Optimal Financing Polices," Journal of Financial Economics 26(1), 3-28.

Williamson, O.E. (1988). “Corporate Finance and Corporate Governance,” Journal of Finance 43(3), 567-591.

Zaher, T.S. (2010). “Performance of Debt Free Firms,” Managerial Finance 36(6), 491-501. 
Table 1

List of Firms with Zero Debt

During Great Recession

December 2007-June 2009

\begin{tabular}{llll}
\hline Ticker Company Name & $\begin{array}{l}\text { Market Cap } \\
(\$ \text { billions })\end{array}$ & Total Debt
\end{tabular}

\section{Technology}

$\begin{array}{llrl}\text { AAPL } & \text { Apple Inc. } & 317.5 & 0 \\ \text { TXN } & \text { Texas Instruments } & 31.7 & 0 \\ \text { CTSH } & \text { Cognizant Technology } & 22.6 & 0 \\ \text { CTXS } & \text { Citrix Systems, I } & 15.7 & 0 \\ \text { ATVI } & \text { Activision Blizza } & 13.5 & 0 \\ \text { CHKP } & \text { Check Point Software } & 18.2 & 0 \\ \text { MRVL } & \text { Marvell Technology } & 17.6 & 0 \\ \text { ADSK } & \text { Autodesk, Inc. } & 14.9 & 0 \\ \text { FFIV } & \text { F5 Networks, Inc. } & 19.9 & 0 \\ \text { RHT } & \text { Red Hat, Inc. Comp. } & 8.9 & 0 \\ \text { ERTS } & \text { Electronic Arts I } & 8.0 & 0 \\ \text { GRMN } & \text { Garmin Ltd. } & 6.4 & 0 \\ \text { AKAM } & \text { Akamai Technology } & 6.1 & 0 \\ \text { INFA } & \text { Informatica Corp. } & 6.0 & 0 \\ \text { NTES } & \text { NetEase.com, Inc. } & 5.9 & 0 \\ \text { RVBD } & \text { Riverbed Technology } & 5.6 & 0 \\ \text { DOX } & \text { Amdocs Limited Co } & 5.4 & 0 \\ \text { PLCM } & \text { Polycom, Inc. } & 5.2 & 0 \\ \text { DLB } & \text { Dolby Laboratories } & 5.1 & 0\end{array}$

\section{$\underline{\text { Services }}$}

$\begin{array}{llcl}\text { AMZN } & \text { Amazon.com, Inc. } & 85.2 & 0 \\ \text { CHRW } & \text { C.H. Robinson } & 12.8 & 0 \\ \text { BBBY } & \text { Bed Bath \& Beyond } & 12.7 & 0 \\ \text { PAYX } & \text { Paychex, Inc. } & 11.1 & 0 \\ \text { RUK } & \text { Reed Elsevier NV } & 10.9 & 0 \\ \text { EXPD } & \text { Expeditors Intern } & 10.7 & 0 \\ \text { CTRP } & \text { Ctrip.com } & 6.5 & 0\end{array}$


Table 1 (continued)

List of Firms with Zero Debt

\begin{tabular}{llll}
\hline Ticker & Company Name & $\begin{array}{l}\text { Market Cap } \\
\text { (\$ billions) }\end{array}$ & Total Debt \\
\hline
\end{tabular}

\section{$\underline{\text { Industrial goods }}$}

$\begin{array}{llcc}\text { FAST } & \text { Fastenal Company } & 9.3 & 0 \\ \text { FLIR } & \text { FLIR Systems, Inc. } & 5.5 & 0 \\ & & \text { Healthcare } & \\ \text { ISRG } & \text { Intuitive Surgical } & 13.5 & 0 \\ \text { FRX } & \text { Forest Laboratories } & 10.6 & 0\end{array}$

\section{Consumer goods}

\begin{tabular}{llcc} 
LULU & lululemon athletic & 6.1 & 0 \\
FOSL & Fossil & 6.3 & 0 \\
HANS & Hansen Natural & $\begin{array}{c}\text { 6.4 } \\
\text { Basic Material }\end{array}$ & 0 \\
\cline { 3 - 3 } & & 7.6 & 0 \\
IAG & Iamgold Corporation & 3.7 & 0 \\
KMR & Kinder Morgan Man & 5.0 & 0 \\
CEF & Central Fund of C & & \\
\hline
\end{tabular}

Table 1 reports names and market capitalization (in \$billions) for the firms that have zero total debt during the period of the great recession, December 2007 through June 2009. 


\begin{tabular}{l} 
Ticker \\
Technology \\
\hline TLk \\
NXPI \\
Auo \\
FLEX \\
CSC \\
MU \\
VIP \\
MBT \\
HRS \\
KLAC \\
TKC \\
STM \\
ASX \\
SNDK \\
CA \\
ALU \\
SYMC \\
TEL \\
TU \\
A \\
APH \\
UMC \\
IRM \\
FTR \\
AMT \\
CCI \\
\end{tabular}

\section{Company Name}

P.T. Telekomunika NXP Semiconductor AU Optronics Corp

Flextronics Inter

Computer Sciences

Micron Technology

VimpelCom Ltd

Mobile TeleSystem

Harris Corp.

KLA-Tencor Corp.

Turkcell Iletisim

STMicroelectronic

Advanced Semicond

SanDisk Corp.

CA Inc.

Alcatel-Lucent

Symantec Corp.

TE Connectivity L

TELUS Corporation

Agilent Technolog

Amphenol Corp.

United Microelect

Iron Mountain Inc.

Frontier Comm

American Tower

Crown Castle Inte

Table 2

List of Leveraged Firms

During Great Recession

December 2007-June 2009

\section{(\$billions)}

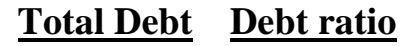

$\begin{array}{rll}17.6 & 2.31 & 0.151 \\ 6.7 & 4.63 & 0.691 \\ 7.1 & 6.53 & 0.919 \\ 5.2 & 2.22 & 0.426 \\ 6.0 & 2.58 & 0.433 \\ 9.2 & 1.74 & 0.188 \\ 18.2 & 5.66 & 0.312 \\ 19.1 & 7.46 & 0.391 \\ 5.9 & 2.07 & 0.349 \\ 6.6 & 0.75 & 0.180 \\ 12.5 & 1.81 & 0.145 \\ 9.6 & 1.75 & 0.182 \\ 7.4 & 2.49 & 0.335 \\ 10.6 & 1.74 & 0.164 \\ 11.5 & 1.55 & 0.155 \\ 12.8 & 6.25 & 0.489 \\ 14.0 & 2.58 & 0.185 \\ 15.9 & 2.75 & 0.173 \\ 16.8 & 7.19 & 0.427 \\ 16.5 & 2.41 & 0.200 \\ 9.2 & 1.95 & 0.211 \\ 6.7 & 1.75 & 0.261 \\ 6.6 & 3.01 & 0.459 \\ 8.5 & 8.27 & 0.975 \\ 20.3 & 5.57 & 0.274 \\ 11.7 & 6.73 & 0.574\end{array}$


Table 2 (continued)

List of Leveraged Firms

$\underline{\text { Ticker }}$

$\underline{\text { Services }}$

MCD

DIS

HD

CVS

UNP

NWSA

TWX

CNI

TGT

LOW

CUK

LVS

CCL

CSX

$\underline{\text { Industrial goods }}$

TYC

WM

RTN

ETN

SWK

RSG

KUB

LUK

BUCY

$\mathrm{X}$

ERJ

Healthcare

BSX

CI

HUM
Company Name

McDonald's Corp.

Walt Disney Comp.

Home Depot

CVS Caremark Corp

Union Pacific Corp

News Corporation

Time Warner Inc.

Canadian National

Target Corp.

Lowe's Companies

Carnival Plc ADS

Las Vegas Sands

Carnival Corp.

CSX Corporation

Tyco International

Waste Management

Raytheon Company

Eaton Corporation

Stanley Black \& D

Republic Services

Kubota Corporation

Leucadia National

Bucyrus Internati

United States Steel

Embraer S.A. Comm

Boston Scientific

CIGNA Corporation

Humana

\section{Mkt Cap Total Debt Debt ratio}

(\$billions)

$\begin{array}{rrr}83.6 & 12.77 & 0.153 \\ 74.4 & 12.79 & 0.172 \\ 55.4 & 10.76 & 0.194 \\ 51.4 & 9.78 & 0.190 \\ 49.6 & 9.20 & 0.185 \\ 45.3 & 15.49 & 0.342 \\ 37.7 & 16.56 & 0.440 \\ 34.8 & 6.06 & 0.174 \\ 32.7 & 15.78 & 0.483 \\ 30.5 & 6.57 & 0.216 \\ 30.5 & 9.31 & 0.305 \\ 30.4 & 10.10 & 0.332 \\ 29.0 & 9.31 & 0.321 \\ 27.8 & 8.14 & 0.292 \\ & & \\ 22.2 & 4.13 & 0.186 \\ 17.6 & 9.16 & 0.520 \\ 17.3 & 3.61 & 0.209 \\ 16.2 & 3.45 & 0.213 \\ 11.7 & 3.60 & 0.307 \\ 11.4 & 6.82 & 0.596 \\ 11.0 & 4.53 & 0.413 \\ 8.1 & 2.09 & 0.256 \\ 7.5 & 1.55 & 0.207 \\ 6.2 & 3.74 & 0.606 \\ 5.6 & 2.05 & 0.367 \\ & & \\ 10.3 & 4.92 & 0.480 \\ 13.1 & 3.23 & 0.247 \\ 13.1 & 1.96 & 0.150\end{array}$




\section{Table 2 (continued) \\ List of Leveraged Firms}

Ticker

Consumer goods

FBR

TRW

TSN

BLL

MKC

HAS

CCK

ST

Basic Material

TYC

WM

RTN

ETN

SWK

RSG

KUB

LUK

BUCY

$\mathrm{X}$

ERJ
Company Name

Fibria Celulose S

TRW Automotive

Tyson Foods

Ball Corporation

McCormick \&

Hasbro

Crown Holdings

Sensata Technolog

Tyco Internationa

Waste Management

Raytheon Company

Eaton Corporation

Stanley Black \& D

Republic Services

Kubota Corporatio

Leucadia National

Bucyrus Internati

United States Ste

Embraer S.A. Comm

\section{Mkt Cap Total Debt $\underline{\text { Debt ratio }}$}

(\$billions)

$\begin{array}{rll}6.9 & 6.13 & 0.891 \\ 6.7 & 1.76 & 0.261 \\ 6.7 & 2.40 & 0.358 \\ 6.4 & 3.52 & 0.548 \\ 6.4 & 0.97 & 0.151 \\ 6.0 & 1.43 & 0.238 \\ 6.0 & 3.47 & 0.582 \\ 6.3 & 1.93 & 0.309 \\ & & \\ 22.2 & 4.13 & 0.186 \\ 17.6 & 9.16 & 0.520 \\ 17.3 & 3.61 & 0.209 \\ 16.2 & 3.45 & 0.213 \\ 11.7 & 3.60 & 0.307 \\ 11.4 & 6.82 & 0.596 \\ 11.0 & 4.53 & 0.413 \\ 8.1 & 2.09 & 0.256 \\ 7.5 & 1.55 & 0.207 \\ 6.2 & 3.74 & 0.606 \\ 5.6 & 2.05 & 0.367\end{array}$

Table 2 reports market capitalization (\$ billions), total debt (\$ billions), and debt to equity ratio for leveraged firms during the period of the great recession, December 2007 through June 2009. 
Table 3: Descriptive Statistics of Debt Free Portfolios and Leveraged Portfolios during Recession of December 2007-June 2009

\begin{tabular}{|c|c|c|}
\hline & Debt Free Firms & Leveraged Firms \\
\hline \multicolumn{3}{|l|}{ Panel A: Technology Sector } \\
\hline $\begin{array}{l}\text { Mean Monthly Return \% } \\
\text { Average Standard Deviation } \\
\text { Average Coefficient of Variation } \\
\text { Average Debt to Ratio } \\
\text { Sample Size }\end{array}$ & $\begin{array}{l}0.011 \\
0.129 \\
12.05 \\
0 \\
19\end{array}$ & $\begin{array}{l}-0.073 \\
0.270 \\
-36.82 \\
0.391 \\
26\end{array}$ \\
\hline \multicolumn{3}{|l|}{ Panel B: Services } \\
\hline $\begin{array}{l}\text { Mean Monthly Return \% } \\
\text { Average Standard Deviation } \\
\text { Average Coefficient of Variation } \\
\text { Average Debt Ratio } \\
\text { Sample Size }\end{array}$ & $\begin{array}{l}0.007 \\
0.143 \\
21.89 \\
0 \\
7\end{array}$ & $\begin{array}{c}-0.011 \\
0.114 \\
-10.87 \\
0.270 \\
14\end{array}$ \\
\hline \multicolumn{3}{|l|}{ Panel C: Industrial Goods Sector } \\
\hline $\begin{array}{l}\text { Mean Monthly Return \% } \\
\text { Average Standard Deviation } \\
\text { Average Coefficient of Variation } \\
\text { Average Debt Ratio } \\
\text { Sample Size }\end{array}$ & $\begin{array}{l}-0.005 \\
0.099 \\
-20.86 \\
0 \\
2\end{array}$ & $\begin{array}{c}-0.006 \\
0.107 \\
-17.06 \\
0.356 \\
11\end{array}$ \\
\hline \multicolumn{3}{|l|}{ Panel D: Health Care Sector } \\
\hline $\begin{array}{l}\text { Mean Monthly Return \% } \\
\text { Average Standard Deviation } \\
\text { Average Coefficient of Variation } \\
\text { Average Debt Ratio } \\
\text { Sample Size }\end{array}$ & $\begin{array}{l}0.003 \\
0.137 \\
46.18 \\
0 \\
3\end{array}$ & $\begin{array}{l}-0.016 \\
0.087 \\
-5.320 \\
0.292 \\
3\end{array}$ \\
\hline
\end{tabular}


Table 3: Descriptive Statistics of Debt Free Portfolios and Leveraged Portfolios during Recession of December 2007-June 2009(continued)

\begin{tabular}{lll}
\hline & Debt Free Firms & Leveraged Firms \\
\hline Panel F: Consumer Goods Sector & & \\
\hline Mean Monthly Return \% & -0.008 & -0.009 \\
Average Standard Deviation & 0.252 & 0.317 \\
Average Coefficient of Variation & -30.48 & 3.353 \\
Average Debt Ratio & 0 & -0.346 \\
Sample Size & 3 & 8 \\
& & \\
\hline Panel G: Basic Materials Sector & & \\
& & -0.034 \\
Mean Monthly Return \% & 0.009 & 0.2656 \\
Average Standard Deviation & 0.095 & -9.829 \\
Average Coefficient of Variation & 9.829 & 0.352 \\
Average Debt Ratio & 0.356 & 12 \\
Sample Size & 3 &
\end{tabular}

Panel J: All Sectors

\begin{tabular}{lll}
\hline Mean Monthly Return \% & 0.003 & -0.087 \\
Average Standard Deviation & 0.110 & 0.192 \\
Average Coefficient of Variation & 40.44 & -0.458 \\
Average Debt Ratio & 0 & -8.802 \\
Sample Size & 37 & 74
\end{tabular}

Table 3 provides the descriptive statistics (mean monthly return, average standard deviation, and average coefficient of variation, average debt to equity ratio, and sample size) of the portfolios of leveraged firms and debt free firms. The $\mathrm{Z}$ scores for the difference in means of monthly return, average standard deviation and average coefficient of variation are $2.65^{*}, 2.13^{*}$, and $1.73^{* *}$ respectively.

* Significant at the $5 \%$ level

$* *$ Significant at the $10 \%$ level 
Table-4 Performance of Portfolios of Debt Free Firms and Portfolios of Leveraged Firms during the December 2007-June 2009 Recession

\section{Debt Free Firms Leveraged Firms}

Panel A: Technology Sector

\begin{tabular}{lll}
\hline Beta & 1.1 & 1.2 \\
Jensen $\alpha$ & $0.022^{*}$ & -0.032 \\
Sharp IR & 0.86 & -0.23
\end{tabular}

Panel B: Services Sector

\begin{tabular}{lll}
\hline Beta & 1.4 & 1.8 \\
Jensen $\alpha$ & $0.017^{*}$ & 0.014 \\
Sharp IR & 0.74 & 0.26
\end{tabular}

Panel C: Industrial goods Sector

\begin{tabular}{lll}
\hline Beta & 1.0 & 1.4 \\
Jensen $\alpha$ & $0.010^{* *}$ & 0.009 \\
Sharp IR & 0.64 & 0.33
\end{tabular}

Panel D: Health Care Sector

\begin{tabular}{lll}
\hline Beta & 1.5 & 2.5 \\
Jensen $\alpha$ & $0.013^{*}$ & -0.002 \\
Sharp IR & 0.98 & 0.43
\end{tabular}

Panel E: Consumer goods Sector

\begin{tabular}{lll}
\hline Beta & 0.7 & 1.1 \\
Jensen $\alpha$ & -0.004 & -0.011 \\
Sharp IR & 0.32 & 0.27 \\
\hline
\end{tabular}


Table-4 Performance of Portfolios of Debt Free Firms and Portfolios of Leveraged Firms during the December 2007-June 2009 Recession (continued)

\section{Debt Free Firms $\quad$ Leveraged Firms}

Panel F: Basic Material Sector

\begin{tabular}{lll}
\hline Beta & 0.7 & 1.0 \\
Jensen $\alpha$ & $0.016^{*}$ & -0.034 \\
Sharp IR & 0.87 & 0.34 \\
\hline
\end{tabular}

Panel G: All Sectors

\begin{tabular}{lll}
\hline Beta & 1.2 & 1.6 \\
Jensen $\alpha$ & $0.016^{*}$ & 0.007 \\
Sharp IR & 1.17 & 0.383
\end{tabular}

Table 4 provides a comparison of portfolio performance using the Jensen's alpha and Sharp information ratio across all the sectors. Jensen's alpha was computed from equation (1) using NASDAQ equally weighted index from the CRSP as a benchmark. The information ratio was annualized by multiplying the monthly IR calculated from equation (3) by the square root of 12, as shown in equation (4). The $\mathrm{Z}$ scores for Estimated Beta, Jensen's alpha and the annualized Sharp information ratio are $0.1830,2.176, *$ and $2.13^{*}$

* Significant at the $5 \%$ level

**Significant at the $10 \%$ level 